\title{
PENYALAHGUNAAN NARKOBA DI KALANGAN REMAJA DALAM PERSPEKTIF ISLAM
}

\author{
Oleh : M. MASJKUR ${ }^{1}$ \\ ( IAI Sunan Giri Bojonegoro )
}

\begin{abstract}
Indonesia is threatened by the danger of drugtrafficking (narcotics, psychotropic and other addictive substances) and its misuse. In the perspective of Islam, the drugtrafficking synonymous with the wine (Al Khamr). It is banned for users, dealers, and manufacturers.

Drugtrafficking and its misuse is dangerous because it can affect the nervous system, resulting in addiction and dependence. Drugs lead to changes in behavior, feeling, perception, and consciousness. In the perspective of Islam, there are three important things to consider in order to prevent the dissemination of drugs, namely: increasing piety of each individual community to God, to enforce the criminal justice system consistent implementation, and recruiting law enforcement officials are cautiousKeywords: Parents, interest in reading, children.
\end{abstract}

Keywords : Drugtrafficking, perspective of Islam.

\section{PENDAHULUAN}

Masa remaja adalah masa transisi, dimana pada masa seperti ini sering terjadi ketidak stabilan baik itu emosi maupun kejiwaan. Pada masa transisi ini

\footnotetext{
${ }^{1}$ Dosen tetap Fakultas Tarbiyah Institut Agama Islam Sunan Giri Bojonegoro
} 
Penyalahgunaan Narkoba Di Kalangan Remaja Dalam Perspektif Islam

juga remaja sedang mencari jati diri sebagai seorang remaja. Namun sering kali dalam pencarian jati diri ini remaja cenderung salah dalam bergaul sehingga banyak melakukan hal yang menyimpang dari norma-norma yang berlaku di masyarakat. Seperti perkelahian dan minum-minuman keras, pencurian, perampokan, perusakan atau pembakaran, seks bebas bahkan narkoba. Perilaku menyimpang remaja tersebut dapat dikatakan sebagai kenakalan remaja.

Kenakalan remaja meliputi semua perilaku yang menyimpang dari norma-norma hukum pidana yang dilakukan oleh remaja. Perilaku tersebut akan merugikan diri remaja sendiri dan orang-orang sekitarnya. Dr Kartini Kartono, seorang ilmuwan patologi berpendapat, kenakalan remaja atau dalam Bahasa Inggris dikenal dengan juvenile delinquency merupakan gejala patologis sosial pada remaja yang disebabkan oleh satu bentuk pengabaian sosial. Akibatnya, mereka mengembangkan bentuk perilaku yang menyimpang. ${ }^{2}$

Secara umum kenakalan remaja didefinisikan sebagai suatu sikap dan perilaku yang menyimpang dari aturan sosial, adat, hukum dan agama.

Dari pengertian di atas dapat disimpulkan bahwa: kenakalan remaja itu adalah perbuatan para remaja yang bertentangan dengan hukum, agama, dan

\footnotetext{
${ }^{2}$ Dr Kartini Kartono, Patologi Sosial 2 Kenakalan Remaja, Rajawali Pers, Jakarta, 2001, hal. 22
}

78 | Vol. 5, No. 9, Edisi 1, Juli-Desember 2016 
norma-norma masyarakat sehingga akibatnya dapat merugikan orang lain, mengganggu ketentraman umum dan juga merusak dirinya sendiri.

Bahwa pengertian kenakalan remaja akhir-akhir ini mulai bergeser. Hal tersebut karena adanya perilaku remaja mengarah pada tindak kejahatan (kriminalitas). Sebagai contoh, bentuk kenakalan remaja pada masa lalu hanya terbatas pada tindakan-tindakan kecil seperti kabur dari rumah, menipu orang tua dan tindakan sejenisnya, namun pada saat ini bentuk kenakalan remaja sudah semakin memprihatinkan mulai dari pencurian sampai pada penyalahgunaan narkoba.

Bahwa narkoba adalah singkatan dari narkotika, psikotropika dam bahan adiktif lainnya. Selain narkoba, istilah lain yang diperkenalkan khususnya oleh Departemen Kesehatan Republik Indonesia adalah "napza" yang merupakan singkatan dari 'Narkotika, Psikotropika dan Zat Adiktif.

Bila narkoba digunakan secara terus menerus atau melebihi takaran yang telah ditentukan akan mengakibatkan ketergantungan. Kecanduan inilah yang akan mengakibatkan gangguan fisik dan psikologis, karena terjadinya kerusakan pada sistem syaraf pusat (SSP) dan organ-organ tubuh seperti jantung, paru-paru, hati dan ginjal.

Dampak penyalahgunaan narkoba pada seseorang sangat tergantung pada jenis narkoba yang dipakai, kepribadian pemakai dan situasi atau kondisi 
Penyalahgunaan Narkoba Di Kalangan Remaja Dalam Perspektif Islam

pemakai. Secara umum, dampak kecanduan narkoba dapat terlihat pada fisik, psikis maupun sosial seseorang.

Bahwa Syari'at islam memerangi dan mengharamkan segala hal yang memabukkan dan segala bentuk narkoba dengan berbagai macam dan jenisnya yang beragam. Karena barang-barang itu mengandung bahaya yang nyata bagi manusia; kesehatan, akal, kehormatan, reputasi, prestis, dan nama baik.

Berdasarkan uraian di atas, maka terdapat tiga permasalahan yang akan dibahas, yaitu:

1. Apa yang dimaksud dengan narkoba itu.

2. Apa penyebab dan bagaimana dampak penyalahgunaan narkoba.

3. Bagaimana penyalahgunaan narkoba dalam perspektif Islam.

Berdasarakan permasalahan yang telah dikemukakan, maka penulisan ini bertujuan untuk mengetahui:

1. Narkoba dengan berbagai jenisnya.

2. Penyebab dan dampak penyalahgunaan narkoba.

3. Penyalahgunaan narkoba dalam perspektif Islam. 


\section{NARKOBA}

\section{A. Pengertian Narkoba}

Narkoba adalah singkatan dari narkotika, psikotropika dam bahan adiktif lainnya. Istilah narkoba berdasarkan Kepres No. 17 tahun 2002 sejak terbentuknya Badan Narkotika Nasional (BNN). ${ }^{3}$ Selain "narkoba", istilah lain yang diperkenalkan khususnya oleh Departemen Kesehatan Republik Indonesia adalah napza yang merupakan singkatan dari 'Narkotika, Psikotropika dan Zat Adiktif.

Semua istilah ini, baik "narkoba" atau napza, mengacu pada sekelompok zat yang umumnya mempunyai resiko kecanduan bagi penggunanya. Menurut pakar kesehatan narkoba sebenarnya adalah psikotropika yang biasa dipakai untuk membius pasien saat hendak dioparasi atau obat-obatan untuk penyakit tertentu. Namun kini presepsi itu disalah gunakan akibat pemakaian yang telah diluar batas dosis. ${ }^{4}$

Narkotika adalah zat atau obat yang berasal dari tanaman atau bukan tanaman, baik sintetis maupun semisintetis, yang dapat menyebabkan penurunan atau perubahan kesadaran, hilangnya rasa, mengurangi

\footnotetext{
${ }^{3}$ Yanuar Sadewa, Bimbingan dan Penyuluhan Islam terhadap Bahaya Narkoba, Makalah Badan Narkotika Nasioal 21 Agustus 2007.

${ }^{4}$ Ahmad Sofyan, Narkoba Mengincar Anak Anda, Prestasi Pustaka, Jakarta, 2007, hal. 12 At Tuhfah Jurnal Keislaman $\mid 81$
} 
Penyalahgunaan Narkoba Di Kalangan Remaja Dalam Perspektif Islam

sampai menghilangkan rasa nyeri, dan dapat menimbulkan ketergantungan. 5

Psikotropika adalah zat atau obat, baik alamiah maupun sintetis bukan narkotika, yang berkhasiat psikoaktif melalui pengaruh selektif pada susunan saraf pusat yang menyebabkan perubahan pada aktivitas mental dan perilaku. ${ }^{6}$

Sedang Bahan Adiktif berbahaya lainnya adalah bahan-bahan alamiah, semi sintetis maupun sintetis yang dapat dipakai sebagai pengganti morfina atau kokaina yang dapat mengganggu sistem syaraf pusat.

Dalam perspektif Islam, narkoba identik dengan Al-khamr yang secara etimologi berarti menutupi. Yang dimaksud khamr itu adalah sesuatu yang menutupi kepala seperti sorban atau kerudung. Dinamakan khamr karena menutupi atau mengacaukan akal. ${ }^{7}$

\footnotetext{
${ }^{5}$ Pasal 1 ayat (1) Undang-Undang RI No. 35 tahun 2009 tentang Narkotika.

${ }^{6}$ Pasal 1 ayat (1) Undang-Undang RI No. 5 tahun 1997 tentang Psikotropika.

${ }^{7}$ Muhammad Ali Al Sayis, Tafsir Ayat al-Ahkam, Jilid 1, Ali Sabih wa Auladuh, t.t., hal. 119
}

82 | Vol. 5, No. 9, Edisi 1, Juli-Desember 2016 
Dalam Bahasa Arab palig sedikit ada tiga istilah tentang narkotika, yaitu al-Mukhaddirat ( المخدرات ), al-Aqaqir ( العقاقير), dan hasyisy ( )$^{8}$

\section{B. Jenis-jenis Narkoba}

Penyebaran penyalahgunaan narkoba sudah hampir tak dapat dicegah. Mengingat hampir seluruh penduduk dunia dapat dengan mudah mendapat narkoba dari oknum-oknum yang tidak bertanggung jawab. Pada saat ini terdapat 35 jenis narkoba yang dikonsumsi pengguna narkoba di Indonesia dari yang paling murah hingga yang mahal seperti LSD. Di dunia terdapat 354 jenis narkoba. Dari sekian banyak jenis narkoba yang sangat rawan disalahgunakan, ada empat jenis narkoba yang paling populer di Indonesia, yaitu: Ganja, shabu, ekstasi, dan heroin. Keempat jenis inilah yang akan dibahas berikut ini.

\section{Ganja (Cannabis sativa syn. Cannabis indica)}

Nama lainnya adalah: cimeng, marijuana, gele, pocong. Adalah tumbuhan budidaya penghasil serat, namun lebih dikenal karena kandungan zat narkotika pada bijinya, tetrahidrokanabinol (THC, tetra-

\footnotetext{
${ }^{8}$ Ahmad Warson al-Munawir, Kamus Arab-Indonesia, Agustus, Yogyakarta, 1984, hal. 351.

At Tuhfah Jurnal Keislaman | 83
} 
Penyalahgunaan Narkoba Di Kalangan Remaja Dalam Perspektif Islam

hydro-cannabinol) yang dapat membuat pemakainya mengalami euforia (rasa senang yang berkepanjangan tanpa sebab). ${ }^{9}$

Marijuana adalah kata yang digunakan untuk menggambarkan bunga, batang, biji dan daun kering dari tanaman ganja, Cannabis sativa, tanaman yang mengandung zat pengubah akal sehat delta-9 tetrahydrocannabiol (THC) dan senyawa lain yang terkait. Marijuana adalah obat terlarang yang paling umum digunakan di seluruh dunia termasuk Indonesia. Orang-orang menggunakan ganja kering/marijuana dengan memasukannya ke dalam lintingan rokok atau ke dalam pipa (bong). Mereka juga terkadang mengosongkan tembakau pada rokok dan diisi dengan marijuana. Untuk menghindari asap yang dihasilkan, banyak orang yang menggunakan alat penguap (vaporizer) yang juga sering disebut bong. Alat ini dapat menarik zat-zat aktif, termasuk THC dari ganja dan mengumpulkan uap mereka di unit penyimpanan. Kemudian seseorang akan menghirup uap tersebut, bukan menghirup asap.

Tumbuhan ganja telah dikenal manusia sejak lama dan digunakan sebagai bahan pembuat kantung karena serat yang dihasilkannya kuat. Biji ganja juga digunakan sebagai sumber minyak. Namun, karena ganja juga dikenal sebagai sumber narkotika dan kegunaan ini lebih bernilai

${ }^{9}$ Drs. A.W. Widjaja, Masalah Kenakalan Remaja dan Penyalahgunaan Narkotika, Armico, Bandung, 2009, hal 14

84 | Vol. 5, No. 9, Edisi 1, Juli-Desember 2016 
ekonomi, orang lebih banyak menanam untuk hal ini dan di banyak tempat disalahgunakan.

Di sejumlah negara penanaman ganja sepenuhnya dilarang. Di beberapa negara lain, penanaman ganja diperbolehkan untuk kepentingan pemanfaatan seratnya. Syaratnya adalah varietas yang ditanam harus mengandung bahan narkotika yang sangat rendah atau tidak ada sama sekali. Sebelum ada larangan ketat terhadap penanaman ganja, di Aceh daun ganja menjadi komponen sayur dan umum disajikan.

\section{Shabu}

Methamphetamine atau yang biasa kita kenal sebagai shabu adalah stimultan obat yang sangat adiktif, yang secara kimiawi mirip dengan amfetamine. Bentuknya putih, tidak berbau, pahit dan seperti kristal. Hasil survey BNN memperlihatkan shabu sebagai narkoba peringkat 2 yang paling sering dikonsumsi oleh masyarakat.

Shabu dapat dikonsumsi dengan cara dimakan, dimasukan ke dalam rokok, dihisap dan dilarutkan dengan air atau alkohol, lalu disuntikan ke tubuh. Merokok atau menyuntikan shabu dapat memberikan efek yang sangat cepat pada otak dan akan menghasilkan euforia yang intens. Karena euforia tersebut dapat memudar dengan cepat, maka pengguna sering memakainya berulang kali. 
Penyalahgunaan Narkoba Di Kalangan Remaja Dalam Perspektif Islam

\section{Ekstasi}

Ekstasi berasal dari kata Ex-Stosis yang berarti terbebas atau juga bisa berarti suatu keadaan yang menyenangkan. Kemungkinan yang dimaksud adalah terbebaskan dari situasi yang biasa-biasa saja sehari-harinya berubah menjadi situasi yang serba hangat, gembira, bahagia dengan bayangan yang indah-indah dan sebagainya. Nama ekstasi merupakan nama jalanan untuk suatu senyawa yang merupakan turunan Amphetomine. ${ }^{10}$

Ekstasi tergolong zat psikotropika. Keberadaan ektasi di Indonesia mulai dikenal pada 1990an dan mulai terkenal pada tahun 1994. Sejak kasus ditemukannya selebriti sebagai penyalagunanya dengan segala dampak buruknya sampai meninggal, sejak saat itu kasus-kasus ektasi mulai merebak, karena banyak terjadi di kalangan selebriti dan ada juga tokoh masyarakat yang tertangkap dan dijebloskan kedalam tahanan dan lembaga pemasyarakatan oleh penegak hukum. Menurut BNN, ekstasi merupakan jenis Narkoba peringkat 3 yang paling sering dikonsumsi.

Ekstasi termasuk ke dalam Psikotropika atau obat keras yang juga dikenal dengan nama MDMA (3,4-methylenedioxy-Nmethylamphetamine). Ekstasi yang diproduksi secara illegal dibuat

${ }^{10}$ Ibid., hal. 17

86 | Vol. 5, No. 9, Edisi 1, Juli-Desember 2016 
dalam bentuk tablet dengan warna yang berbeda beda serta desain yang berbeda-beda pula. Selain itu ekstasi juga diproduksi dalam bentuk bubuk juga kapsul. Cara pakainya dikunyah, dikulum, ditelan dengan air mineral. Harganya sangat mahal sehingga hanya dipakai kelas menengah keatas, executive dll. ${ }^{11}$

\section{Heroin}

Heroin atau putaw merupakan golongan narkotika semisintetis yang dihasilkan atas pengolahan morfin secara kimiawi melalui 4 tahapan sehingga diperoleh heroin paling murni berkadar $80 \%$ hingga 99\%. Heroin murni berbentuk bubuk putih sedangkan heroin tidak murni berwarna putih keabuan (street heroin). Zat ini sangat mudah menembus otak sehingga bereaksi lebih kuat dari pada morfin itu sendiri. Umumnya digunakan dengan cara disuntik atau dihisap. ${ }^{12}$

Heroin sebenarnya berasal dari tanaman candu atau opium. Tanaman candu menghasilkan komponen yang bernama morphine, heroin, dan codein. Tanaman ini pun telah lama dikenal di Indonesia yang digunakan oleh orang-orang tua terutama keturunan cina dengan menghisap atau dikenal dengan madat. Sebetulnya, candu adalah getah

\footnotetext{
${ }^{11}$ Subagyo Partodihardjo, Kenali Narkoba dan Musuhi Penyalahgunaannya, Esensi, Jakarta, 2000 , hal. 32

${ }^{12}$ Ibid., hal. 26
} 
Penyalahgunaan Narkoba Di Kalangan Remaja Dalam Perspektif Islam dari tanaman yang dikenal dengan Papaver somniferum. Getah tersebut dihasilkan oleh buah papaver yang hampir masak dan mengalami luka akibat goresan yang sengaja dibuat. Dari luka tersebut, akan muncul getah papaver yang nantinya akan mengering di atas kulit buahnya. Getah tersebut berwarna coklat tua dan memiliki bau yang kurang sedap, serta rasanya pahit. Negara produsen candu yang cukup besar adalah Burma, Thailand, dan Laos. Dalam perdagangan gelap, candu biasanya dipasarkan dalam bentuk candu masak, candu mentah, morfin, dan heroin.

Menurut hasil survey BNN, Heroin merupakan jenis narkoba peringkat ke-4 yang paling banyak dikonsumsi.

Meski banyak narkotika yang berasal dari tanaman, namun keterbatasan bahan baku tersebut kian membuat narkotika sintetik menjadi berkembang. Narkotika sintetik berasal dari bahan-bahan kimia yang diolah di laboraturium. Jenis narkotika sintetik yang banyak tersebar luas adalah meperidin dan methodon. Penyalahgunaan jenis narkotika ini pun memiliki efek dan ketergantungan yang sama dengan narkotika lainnya, yaitu sama bahayanya. Meski narkotika sangat manjur sebagai obat-obat penghilang rasa sakit, namun upaya untuk menghasilkan obat sejenis yang tidak 
menimbulkan ketagihan terus dilakukan. Harapannya, konsumsi narkotika terutama secara illegal menjadi berkurang dan kesadaran masyarakat terhadap kesehatan menjadi meningkat.

\section{PENYEBAB DAN DAMPAK PENYALAHGUNAAN NARKOBA}

\section{A. Faktor Penyebab Penyalahgunaan Narkoba}

Penyalahgunaan narkoba adalah penggunaan narkoba yang bukan untuk tujuan pengobatan, tetapi agar dapat menikmati pengaruhnya, dalam jumlah berlebih, secara kurang lebih teratur, berlangsung cukup lama, sehingga menyebabkan gangguan kesehatan fisik, gangguan kesehatan jiwa dan kehidupan sosialnya. ${ }^{13}$

Menurut Badan Narkotika Nasional Republik Indonesia, terdapat 3 faktor (alasan) yang dapat dikatakan sebagai "pemicu" seseorang dalam penyalahgunakan narkoba. Ketiga faktor tersebut adalah faktor diri, faktor lingkungan, dan faktor kesediaan narkoba itu sendiri. ${ }^{14}$

\footnotetext{
${ }^{13}$ Lydia H. Martono, Satya Joewana, Belajar Hidup Bertanggung Jawab, Menangkal Narkoba dan Kekerasan, Balai Pustaka, Jakarta, 2008, hal.43

${ }^{14}$ Badan Narkotika Nasional Republik Indonesia, Advokasi Pencegahan Penyalahgunaan Narkoba, BNN-RI, Jakarta, 2009, hal. 50
} 
Penyalahgunaan Narkoba Di Kalangan Remaja Dalam Perspektif Islam

Secara umum terdapat dua faktor yang menjadi penyebab penyalahgunaan narkoba, terutama di kalangan remaja, yaitu faktor internal dan faktor eksternal.

\section{Faktor Internal}

Faktor internal terdiri dari faktor kepribadian dan lemahnya pemahaman agama.

\section{a. Kepribadian}

1) Kontrol diri yang buruk

Rasa ingin tahu pada remaja sangat tinggi sehingga ketika seorang remaja menerima suatu informasi, mereka cenderung mencari tahu. Remaja yang ingin tahu kemudian mencoba menggunakan narkoba. Biasanya remaja tersebut memiliki sedikitnya pengetahuan tentang efek-efek narkoba yang ditimbulkan, atau setidaknya norma-norma yang berlaku dan hukum melarang akan penggunaan narkoba. Remaja tersebut tidak dapat mengontrol keinginannya untuk mencobanya, sehingga ia ketagihan obat-obatan tersebut. ${ }^{15}$

2) Pengambilan keputusan yang tidak tepat

${ }^{15}$ Singgih D. Gunarsa, Psikologi Praktis : Anak, Remaja dan Keluarga, Gunung Mulia, Jakarta, 2004, hal.182

90 | Vol. 5, No. 9, Edisi 1, Juli-Desember 2016 
Remaja cendrung mngalami benturan-benturan konflik yang menimbulkan frustrasi sehingga membuat remaja mengambil keputusan tanpa berpikir panjang atau salah mengambil keputusan dengan terlibat dalam penyalahgunaan narkoba untuk mengurangi beban atau kecemasan yang ditimbulkan oleh konflik yang dihadapinya.

3) Prinsip kesenangan semata

Remaja yang terbiasa pada kesenangan semata akan menghindari permasalahan yang lebih rumit, dan biasanya mereka lebih menyukai penyelesaian masalah secara instan, dan praktis atau membutuhkan waktu yang singkat. Sehingga Mereka tidak terbiasa bersikap sabar, telaten, ulet atau berpikir konstruktif akan memilih cara-cara yang simple yang dapat memberikan kesenangan dalam menghadapi permasalahan. seharusnya sikap sabar, telaten, ulet atau berpikir konstruktif akan memilih cara-cara yang simple yang dapat memberikan kesenangan dimiliki oleh seorang remaja bukannya memilih narkoba sebagai pemberi kesenangan. ${ }^{16}$

\section{b. Lemahnya Pemahaman Agama}


Penyalahgunaan Narkoba Di Kalangan Remaja Dalam Perspektif Islam

Agama merupakan benteng moral dari seorang remaja menghadapi hal-hal negatif yang mempengaruhi jiwa. Sehingga untuk melakukan sesuatu khususnya yang dilarang dalam agamanya, seperti menggunakan narkoba, remaja tersebut enggan untuk melakukan hal tersebut dan membantu dalam pengambilan keputusan yang tepat.

\section{Faktor Eksternal}

Faktor eksternal terdiri dari faktor keluarga, faktor lingkungan, dan faktor pendidikan.

\section{a. Faktor Keluarga}

Pada era modern ini orang tua cenderung mengejar karier sehingga terlalu sibuk dan jarang mempunyai waktu untuk mengontrol anak-anaknya, semua dipasrahkan pada guru di sekolah. Remaja yang kurang perhatian dari orang tuanya cenderung mencari perhatian dari luar, biasanya mereka juga mencari "kesibukan" bersama temantemannya. Sehingga membuat remaja tidak mengenal norma-norma yang kebanyakan diperoleh dalam keluarga, dan remaja cenderung bermoral buruk. Karena kurangnya control dari orang tua remaja rentan sekali menggunakakan narkoba karena pengaruh dari temannya, bahkan kerap terjadi saat seorang remaja tertangkap karena 
kasus narkoba, orang tua menjadi orang terakhir yang tua atau mengatakan "Anak saya tidak mungkin memakai narkoba”.

Selain dibutuhkannya kontrol dalam keluarga juga perlu disiplin dan tanggung jawab dalam keluarga. Pengenalan anak terhadap disiplin dan tanggung jawab akan mengurang resiko anak terjebak didalamnya. Anak mempunyai tanggungjawab terhadap dirinya dan orangtua dan juga masyarakat akan mempertimbangkan beberapa hal untuk mencoba-coba menggunakan narkoba. ${ }^{17}$

\section{b. Faktor Lingkungan}

1) Masyarakat sekitar

Lingkungan yang individualis seperti yang terdapat dalam kehidupan kota besar cenderung kurang peduli dengan orang lain, dalam artian setiap individu hanya memikirkan permasalahan dirinya tanpa peduli dengan orang sekitarnya, biasanya orang-orang seperti ini selalu beranggapan bahwa yang penting bukan dirinya, saudara atau familinya tidak terlibat narkoba maka ia tidak mau ambil pusing karenanya. Akibatnya banyak masyarakat yang kurang peduli dengan penyalahgunaan narkoba ini semakin meluas pada remaja.

2) Pergaulan 
Penyalahgunaan Narkoba Di Kalangan Remaja Dalam Perspektif Islam

Pengaruh pergaulan remaja dengan teman sebaya atau kelompok juga berperan penting terhadap penggunaan narkoba. Biasanya berawal dari ikut-ikutan teman. Terlebih bagi seseorang yang memiliki mental dan keperibadian cukup lemah, akan mudah terjerumus. Hal ini disebabkan sebagai syarat kemudahan untuk dapat diterima oleh anggota kelompok. Kelompok atau genk mempunyai kebiasaan perilaku yang sama antar sesama anggota. Jadi tidak aneh bila kebiasaan berkumpul ini juga mengarahkan perilaku yang sama untuk mengkonsumsi narkoba bersama pula. ${ }^{18}$

\section{c. Faktor Pendidikan}

Pendidikan akan bahayanya narkoba di sekolah-sekolah masih minim. Perlu adanya kampanye dari pihak pemerintah maupun instansi terkait untuk menyelamatkan generasi muda bangsa dari pengaruh narkoba. Kurangnya pengetahuan yang dimiliki oleh siswa akan bahayanya narkoba juga dapat memberikan andil terhadap meluasnya pengguna narkoba di kalangan pelajar.

\section{B. DAMPAK PENYALAHGUNAAN NARKOBA}

\footnotetext{
${ }^{18}$ Hendra Surya, Jadilah Pribadi Yang Unggul, Gramedia, Jakarta, 2010, hal.13
} 
Bukan rahasia lagi, bahwa banyak narkoba beredar di pasaran, misalnya ganja, sabu-sabu, ekstasi, dan pil koplo. Penyalahgunaan obat jenis narkoba sangat berbahaya karena dapat mempengaruhi susunan syaraf, mengakibatkan ketagihan, dan ketergantungan. Narkoba menimbulkan perubahan perilaku, perasaan, persepsi, dan kesadaran.

Pemakaian narkoba secara umum dan juga psikotropika yang tidak sesuai dengan aturan dapat menimbulkan efek yang membahayakan tubuh. Ada tiga efek penting yang ditimbulkan oleh penyalahgunaan narkoba, yaitu:

1. Depresan, yaitu menekan sistem sistem syaraf pusat dan mengurangi aktifitas fungsional tubuh sehingga pemakai merasa tenang, bahkan bisa membuat pemakai tidur dan tak sadarkan diri. Bila kelebihan dosis bisa mengakibatkan kematian. Jenis narkoba depresan antara lain opioda, dan berbagai turunannya seperti morphin dan heroin. Contoh yang populer sekarang adalah Putaw.

2. Stimulan, merangsang fungsi tubuh dan meningkatkan kegairahan serta kesadaran. Jenis stimulan: Kafein, Kokain, Amphetamin. Contoh yang sekarang sering dipakai adalah Shabu-shabu dan Ekstasi.

3. Halusinogen, efek utamanya adalah mengubah daya persepsi atau mengakibatkan halusinasi. Halusinogen kebanyakan berasal dari tanaman seperti mescaline dari kaktus dan psilocybin dari jamur-jamuran. Selain 
Penyalahgunaan Narkoba Di Kalangan Remaja Dalam Perspektif Islam

itu ada jugayang diramu di laboratorium seperti LSD. Yang paling banyak dipakai adalah marijuana atau ganja. ${ }^{19}$

Bila narkoba digunakan secara terus menerus atau melebihi takaran yang telah ditentukan akan mengakibatkan ketergantungan. Kecanduan inilah yang akan mengakibatkan gangguan fisik dan psikologis, karena terjadinya kerusakan pada sistem syaraf pusat (SSP) dan organ-organ tubuh seperti jantung, paru-paru, hati dan ginjal.

Dampak penyalahgunaan narkoba pada seseorang sangat tergantung pada jenis narkoba yang dipakai, kepribadian pemakai dan situasi atau kondisi pemakai. Secara umum, dampak kecanduan narkoba dapat terlihat pada fisik, psikis maupun sosial seseorang.

\section{Dampak penyalahgunaan narkoba terhadap fisik}

a. Gangguan pada system syaraf (neurologis) seperti: kejang-kejang, halusinasi, gangguan kesadaran, kerusakan syaraf tepi.

b. Gangguan pada jantung dan pembuluh darah (kardiovaskuler) seperti: infeksi akut otot jantung, gangguan peredaran darah.

c. Gangguan pada kulit (dermatologis) seperti: penanahan (abses), alergi, eksim.

${ }^{19}$ Badan Narkotika Nasional Republik Indonesia, Op. Cit., hal. 61

96 | Vol. 5, No. 9, Edisi 1, Juli-Desember 2016 
d. Gangguan pada paru-paru (pulmoner) seperti: penekanan fungsi pernapasan, kesukaran bernafas, pengerasan jaringan paru-paru.

e. Sering sakit kepala, mual-mual dan muntah, murus-murus, suhu tubuh meningkat, pengecilan hati dan sulit tidur.

f. Dampak penyalahgunaan narkoba terhadap kesehatan reproduksi adalah gangguan padaendokrin, seperti: penurunan fungsi hormon reproduksi (estrogen, progesteron, testosteron), serta gangguan fungsi seksual.

g. Dampak penyalahgunaan narkoba terhadap kesehatan reproduksi pada remaja perempuan antara lain perubahan periode menstruasi, ketidakteraturan menstruasi, dan amenorhoe (tidak haid).

h. Bagi pengguna narkoba melalui jarum suntik, khususnya pemakaian jarum suntik secara bergantian, risikonya adalah tertular penyakit seperti hepatitis $\mathrm{B}, \mathrm{C}$, dan HIV yang hingga saat ini belum ada obatnya.

i. Penyalahgunaan narkoba bisa berakibat fatal ketika terjadi over dosis yaitu konsumsi narkoba melebihi kemampuan tubuh untuk menerimanya. Over dosis bisa menyebabkan kematian.

\section{Dampak penyalahgunaan narkoba terhadap psikis}

a. Lamban kerja, ceroboh kerja, sering tegang dan gelisah. 
Penyalahgunaan Narkoba Di Kalangan Remaja Dalam Perspektif Islam

b. Hilang kepercayaan diri, apatis, pengkhayal, penuh curiga.

c. Agitatif, menjadi ganas dan tingkah laku yang brutal.

d. Sulit berkonsentrasi, perasaan kesal dan tertekan.

e. Cenderung menyakiti diri, perasaan tidak aman, bahkan bunuh diri

\section{Dampak penyalahgunaan narkoba terhadap lingkungan}

\section{sosial}

a. Gangguan mental, anti-sosial dan asusila, dikucilkan oleh lingkungan.

b. Merepotkan dan menjadi beban keluarga.

c. Pendidikan menjadi terganggu, masa depan suram.

Dampak fisik, psikis dan sosial berhubungan erat. Ketergantungan fisik akan mengakibatkan rasa sakit yang luar biasa (sakaw) bila terjadi putus obat (tidak mengkonsumsi obat pada waktunya) dan dorongan psikologis berupa keinginan sangat kuat untuk mengkonsumsi (bahasa gaulnya sugest). Gejata fisik dan psikologis ini juga berkaitan dengan gejala sosial seperti dorongan untuk membohongi orang tua, mencuri, pemarah, manipulatif, dan lain-lain.

98 | Vol. 5, No. 9, Edisi 1, Juli-Desember 2016 


\section{PENYALAHGUNAAN NARKOBA DALAM PERSPEKTIF ISLAM}

\section{A. Hukum Menyalahgunakan Narkoba}

Narkotika dan minuman keras telah lama dikenal umat manusia. Tapi sebenarnya lebih banyak madharatnya daripada manfaatnya. Untuk itu, hampir semua agama besar melarang umat manusia untuk mengkonsumsi narkotika dan minuman keras (dalam bentuk yang lebih luas lagi adalah narkoba).

Dalam wacana Islam, ada beberapa ayat Al-Qur'an dan hadits yang melarang manusia untuk mengkonsumsi minuman keras dan hal-hal yang memabukkan. Pada orde yang lebih mutakhir, minuman keras dan hal-hal yang memabukkan bisa juga dianalogikan (disamakan/diqiaskan) sebagai narkoba. Waktu Islam lahir dari terik padang pasir lewat Nabi Muhammad, zat berbahaya yang paling populer memang baru minuman keras (khamar). Dalam perkembangan dunia Islam, khamar kemudian bergesekan, bermetamorfosa dan beranak pinak dalam bentuk yang makin canggih, yang kemudian lazim disebut narkotika atau lebih luas lagi narkoba.

Untuk itu, dalam analoginya, larangan mengonsumsi minuman keras dan hal-hal yang memabukkan, adalah sama dengan larangan mengonsumsi narkoba.

Dalam Al Qur'an Surat Al Maidah ayat 90 disebutkan: 
Penyalahgunaan Narkoba Di Kalangan Remaja Dalam Perspektif Islam

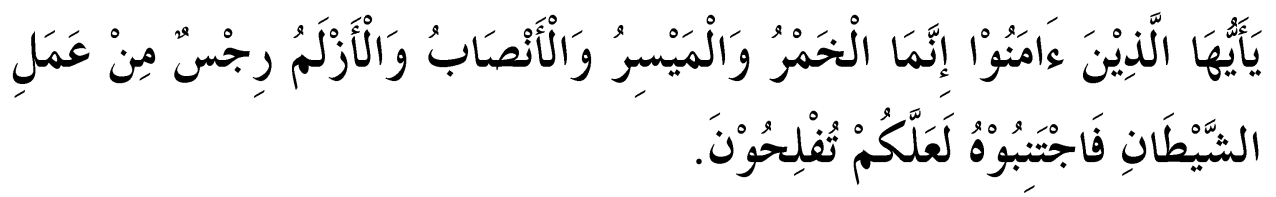

"Wahai orang-orang yang beriman! Sesungguhnya minuman keras, berjudi, (berkurban untuk) berhala, dan mengundi nasib dengan anak panah, adalah perbuatan keji dan termasuk perbuatan setan. Maka jauhilah (perbuatan-perbuatan) itu agar kamu beruntung", ${ }^{20}$

Sejalan dengan ayat di atas, dalam hadits Nabi SAW yang diriwayatkan dari Ummu Salamah menyebutkan:

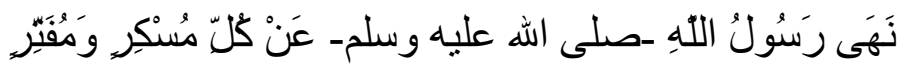

"Rasulullah shallallahu 'alaihi wa sallam melarang dari segala yang memabukkan dan mufattir (yang membuat lemah)" (HR. Abu Daud dan Ahmad).

Dalam hadits yang lain yang diriwayatkan dari Ibnu Umar disebutkan yang artinya:

"Rasulullah melaknat sepuluh orang yang terkait dengan khamr: Produsennya (pembuat), distributornya (pengedar), peminumnya, pembawanya (kurir), pengirimnya, penuangnya (penyuguh), Penjualnya,

${ }^{20}$ Departemen Agama RI, Al Qur'an dan Terjemahnya, CV. Pustaka Agung Harapan, Surabaya, 2006, hal. 163

100 | Vol. 5, No. 9, Edisi 1, Juli-Desember 2016 
pemakan hasil penjualannya, pembayar dan pemesannya" (HR. Ibnu Majah dan Al-Tirmidzi). ${ }^{21}$

Dari dalil-dalil di atas jelaslah, bahwa khamar (narkoba) bisa memerosokkan seseorang ke derajat yang rendah dan hina karena dapat memabukkan dan melemahkan. Untuk itu, khamar (dalam bentuk yang lebih luas adalah narkoba) dilarang dan diharamkan. Sementara itu, orang yang terlibat dalam penyalahgunaan khamar (narkoba) dilaknat oleh Allah, entah itu pembuatnya, pemakainya, penjualnya, pembelinya, penyuguhnya, dan orang yang mau disuguhi.

Sebenarnya jauh-jauh hari, masalah narkoba ini sudah direspon oleh Majelis Ulama Indonesia (MUI) dengan fatwa haram terhadap peredaran dan penyalahgunaan narkoba yang dikeluarkan pada tanggal 10 Pebruari 1976.

\section{B. Pencegahan dan Solusi Penyalahguaan Narkoba dalam Perspektif}

\section{Islam}

Pencegahan remaja dari penyalahgunaan narkoba adalah sangat penting.

Sebab remaja adalah aset masa depan bangsa dan negara. Baik buruknya suatu negara dihari depan bergantung kepada generasi mudanya hari ini

\footnotetext{
${ }^{21}$ Al-Tirmidzi, Jami’ al-Shahih, III, Dar al-Fikr, t.t. hal. 589
}

At Tuhfah Jurnal Keislaman | 101 
Penyalahgunaan Narkoba Di Kalangan Remaja Dalam Perspektif Islam

Bila generasi muda hari ini sudah dinodai oleh narkoba maka akan hancur. Oleh karena itu untuk mencegah hal ini supaya jangan sampai terjadi, maka sudah menjadi tanggung jawab kita bersama, dalam rangka pencegahan penyalahgunaan narkoba dikalangan remaja.

Pencegahan narkoba, terutama yang dapat diberlakukan di kalangan remaja menurut perspektif Islam adalah sebagai berikut:

1. Mengusahakan ikatan yang kuat di dalam keluarga.

2. Pengawasan orang tua yang didasarkan pada aturan tingkah laku yang jelas dan pelibatan orang tua dalam kehidupan anak/remaja.

3. Keberhasilan di sekolah.

4. Ikatan yang kuat di dalam institusi pro-sosial seperti keluarga, sekolah, dan organisasi-organisasi keagamaan.

5. Menerima norma kebiasaan tentang larangan penggunaan narkoba.

6. Keluarga harus dapat menciptakan komunikasi yang lebih baik.

7. Disiplin, tegas dan konsisten dengan aturan yang dibuat.

8. Berperan aktif dalam kehidupan anak-anak.

9. Memonitor aktivitas mereka.

10. Mengetahui dengan siapa anak/remaja bergaul.

11. Mengerti masalah dan apa yang menjadi perhatian mereka.

12. Orang tua harus menjadi panutan. 
13. Orang tua menjadi teman diskusi.

M. Masjkur

14. Orang tua menjadi tempat bertanya.

15. Mampu mengembangkan tradisi keluarga dan nilai-nilai keagamaan.

16. Menggali potensi anak untuk dikembangkan melalui berbagai macam kegiatan. $^{22}$

Di samping hal-hal tersebut di atas, pencegahan narkoba dalam perspektif Islam juga dapat dilakukan melalui bimbingan agama (dakwah Islamiyah). Dakwah Islamiyah untuk pencegahan narkoba ini hendaknya memperhatikan beberapa hal yaitu:

1. Pihak-pihak yang menangani dakwah Islamiyah ini hendaknya terdiri dari pelbagai aspek disiplin ilmu yang terdiri dari: Ulama (kyai, ustadz), psikolog, kriminolog, psikiater, dokter, praktisi hukum, sosiolog, aparat keamanan (polisi), dan pihak-pihak lain yang terkait dalam permasalahan narkoba.

2. Persiapan yang matang dan perencanaan yang rapih dan programprogram yang terarah, efektif, effisien dan profesional. Sehingga dapat mencapai hasil yang maksimal dan memuaskan.

3. Bimbingan tersebut jangan berbentuk ancaman, intimidasi dan tekanan. Tetapi diusahakan dengan menggali potensi diri (tazkiyah al-qalb) akan

${ }^{22}$ M. Arief Hakim, Bahaya Narkoba dan Alkohol : Cara Islam Mengatasi, Mencegah dan Melawan, Nuansa, Bandung, 2004, hal. 97-98.

At Tuhfah Jurnal Keislaman | 103 
Penyalahgunaan Narkoba Di Kalangan Remaja Dalam Perspektif Islam

tergerak untuk mengikuti Al Qur'an dan Hadits. Sehingga dengan penuh kesadaran menjalankan perintah Allah dan menjauhi laranganNya.

4. Bimbingan didesain sedemikian rupa dalam bentuk ceramah/seminar/diskusi dengan seramah dan semudah mungkin, sehingga dapat dirasakan manfaatnya oleh masyarakat.

5. Perpaduan gerakan sosial, kultural dan moral spiritual yang secara langsung melibatkan peran orang tua, tokoh masyarakat, tokoh agama, para pendidik dan aksi nyata pemerintah merupakan langkah yang efektif dan perlu ditumbuh kembangkan di masa yang akan datang.

6. Gerakan dakwah yang dipublikasikan melalui siaran agama pada beberapa stasiun televisi, cukup variatif dan bahkan dinamis, menyangkut penanggulangan dan penanganan rehabilitasi bagi korban penyalahgunaan narkoba. $^{23}$

Adapun solusi yang dapat dilakukan ketika ada seseorang terutama anggota keluarga yang menggunakan narkoba adalah:

1. Berusaha tenang, kendalikan emosi, jangan marah dan tersinggung.

2. Jangan tunda masalah, hadapi kenyataan, adakan dialog terbuka dengan anak.

${ }^{23}$ Nasaruddin Umar, Peran Departemen Agama dalam Pelaksanaan Terapi dan Rehabilitasi Korban Penyalahgunaan Narkoba, disajikan dalam Lokakarya Peran Institut Agama dalam Penanganan Korban Penyalahgunaan Narkoba, Badan Narkotika Nasional (BNN) RI Jakarta, 15 Agustus 2007. 
3. Dengarkan anak, beri dorongan non verbal. Jangan memberi ceramah/nasehat berlebih.

4. Hargai kejujuran.

5. Jujur terhadap diri sendiri, jangan merasa benar sendiri.

6. Tingkatkan hubungan dalam keluarga, rencanakan membuat kegiatan bersama-sama keluarga.

7. Cari pertolongan, cari bantuan pihak ketiga yang paham dalam menangani narkoba atau tenaga profesional, puskesmas, rumah sakit, panti/tempat rehabilitasi.

8. Pendekatan kepada orang tua teman anak pemakai narkoba, ungkapkan dengan hati-hati dan ajak mereka bekerja sama menghadapi masalah. ${ }^{24}$

Di samping hal di atas, untuk penyembuhan korban narkoba terdapat beberapa tempat rehabilitasi di Indonesia yang menggunakan ajaran Islam sebagai acuan di dalam menanggulangi bagi para pengguna narkoba. Di antaranya adalah:

1. Pondok Pesantren Suryalaya dengan metode INABAH yang dikembangkan oleh Abah Anom. Dalam literatur tasawuf, inabah berarti kembali kepada Allah. Maksudnya mengembalikan orang dari perilaku yang selalu menentang kehendak Allah atau maksiat kepada perilaku yang sesuai dengan kehendak Allah. 
Penyalahgunaan Narkoba Di Kalangan Remaja Dalam Perspektif Islam

2. Rumah Penyembuhan Narkoba Yayasan Taubatan Nasuha Jakarta, yang mengembangkan metode 4 in 1 di dalam upaya penyembuhan narkoba bagi korban penyalahgunaan narkoba. Metode ini beranggapan bahwa korban narkoba yang dirawat bukanlah pasien. Mereka tidak perlu diawasi secara ketat, bahkan diberi kebebasan. Tak ada istilah berobat, yang ada adalah wisata hati.

3. Rumah Sakit Ketergantungan Obat (RSKO) Fatmawati Jakarta. Mengembangkan sistem terpadu, yang merupakan gabungan terapi modern dengan terapi gaya pesantren.

Disamping hal-hal teknis yang telah dikemukakan dalam rangka mencegah dan menanggulangi penyalahgunaan narkoba, ada tiga hal penting yang perlu dipertimbangkan dalam rangka mencegah penyebarluasan narkoba, yaitu:

1. Meningkatkan ketakwaan setiap individu masyarakat kepada Allah. Ketakwaan setiap individu masyarakat akan menjadi kontrol bagi masing-masing, sehingga mereka akan tercegah untuk mengkonsumsi, mengedarkan apalagi membuat narkoba. 
2. Menegakkan sistem hukum pidana yang konsisten penerapannya, dengan menjatuhkan hukuman yang berat bagi pengguna, pengedar, maupun pemproduksi narkoba.

3. Merekrut aparat penegak hukum yang bertakwa. Dengan sistem hukum pidana yang tegas, serta aparat penegak hukum yang bertakwa, hukum tidak akan diperjualbelikan. Ini karena tatkala menjalankan tugasnya, aparat penegak hukum yang bertakwa sadar betul, bahwa mereka sedang menjalankan tugas karena Allah, yang akan mendatangkan pahala jika mereka amanah dan akan mendatangkan dosa jika mereka menyimpang atau berkhianat.

Demikian pembahasan tentang penyalahgunaan narkoba dengan berbagai seluk-beluknya, serta bagaimana solusi mengatasinya dalam perspektif Islam.

\section{PENUTUP}

\section{A. Kesimpulan}

Dari pembahasan di atas dapat disimpulkan:

Narkoba adalah singkatan dari narkotika, psikotropika dam bahan adiktif lainnya. Selain narkoba, istilah lain yang diperkenalkan khususnya At Tuhfah Jurnal Keislaman | 107 
Penyalahgunaan Narkoba Di Kalangan Remaja Dalam Perspektif Islam

oleh Departemen Kesehatan Republik Indonesia adalah napza yang merupakan singkatan dari Narkotika, Psikotropika dan Zat Adiktif.

Dalam perspektif Islam, narkoba identik dengan Al-khamr yang secara etimologi berarti menutupi. Yang dimaksud khamr itu adalah sesuatu yang menutupi kepala seperti sorban atau kerudung. Dinamakan khamr karena menutupi atau mengacaukan akal.

Pada saat ini terdapat 35 jenis narkoba yang dikonsumsi pengguna narkoba di Indonesia dari yang paling murah hingga yang mahal seperti LSD. Di dunia terdapat 354 jenis narkoba. Dari sekian banyak jenis narkoba yang sangat rawan disalahgunakan, ada empat jenis narkoba yang paling populer di Indonesia, yaitu: Ganja, shabu, ekstasi, dan heroin.

Terdapat 3 faktor (alasan) yang dapat dikatakan sebagai "pemicu" seseorang dalam penyalahgunakan narkoba. Ketiga faktor tersebut adalah faktor diri, faktor lingkungan, dan faktor kesediaan narkoba itu sendiri.

Penyalahgunaan narkoba sangat berbahaya karena dapat mempengaruhi susunan syaraf, mengakibatkan ketagihan, dan ketergantungan. Narkoba menimbulkan perubahan perilaku, perasaan, persepsi, dan kesadaran.

Dalam perspektif Islam, khamar (dalam bentuk yang lebih luas adalah narkoba) dilarang dan diharamkan. Sementara itu, orang yang 
terlibat dalam penyalahgunaan khamar (narkoba) dilaknat oleh Allah, entah itu pembuatnya, pemakainya, penjualnya, pembelinya, penyuguhnya, dan orang yang mau disuguhi.

Ada tiga hal penting yang perlu dipertimbangkan dalam rangka mencegah penyebarluasan narkoba, yaitu: meningkatkan ketakwaan setiap individu masyarakat kepada Allah, menegakkan sistem hukum pidana yang konsisten penerapannya, dan merekrut aparat penegak hukum yang bertakwa.

\section{B. Saran-saran}

\section{Bagi Orang Tua}

Hendaknya para orang tua harus menciptakan hubungan yang harmonis antara sesama keluarga, dengan cara saling menghargai sesama anggota keluarga.

Hendaknya orang tua harus bijak dalam bersikap dan mendidik anak di mana dan kapan kita harus bersikap keras dan lembut, baik buruknya seorang anak tergantung kepada pendidikan di dalam keluarganya. Sebagai orang tua kita harus banyak luangkan waktu untuk memperhatikan perkembangan fisik, psikis, emosi remaja serta bagaimana untuk menjadi remaja yang kreatif, inovatif dan berprestasi. 
2. Bagi Pemerintah

Hendaknya pemerintah lebih aktif memberikan penyuluhan tentang bahaya penggunaan narkoba kepada anak didik. Beserta menambahkan pengetahuan tentang bahayanya narkoba.

3. Bagi Masyarakat

Hendaknya pengetahuan masyarakat tentang narkoba perlu ditingkatkan. Dengan bertambahnya pengetahuan masyarakat tentang narkoba dapat mencegah penyalahgunaan narkoba secara dini.

\section{DAFTAR KEPUSTAKAAN}

Kartono, Kartini, Patologi Sosial 2 Kenakalan Remaja, Rajawali Pers, Jakarta, 2001

Sadewa, Yanuar, Bimbingan dan Penyuluhan Islam terhadap Bahaya Narkoba, Makalah Badan Narkotika Nasioal 21 Agustus 2007

Sofyan, Ahmad, Narkoba Mengincar Anak Anda, Prestasi Pustaka, Jakarta, 2007

Undang-Undang RI No. 35 tahun 2009 tentang Narkotika.

Undang-Undang RI No. 5 tahun 1997 tentang Psikotropika

Al Sayis, Muhammad Ali, Tafsir Ayat al-Ahkam, Jilid 1, Ali Sabih wa Auladuh, t.t 
Al Munawir, Ahmad Warson, Kamus Arab-Indonesia, Agustus, Yogyakarta, 1984

Widjaja, A.W, Masalah Kenakalan Remaja dan Penyalahgunaan Narkotika, Armico, Bandung, 2009

Partodihardjo, Subagyo, Kenali Narkoba dan Musuhi Penyalahgunaannya, Esensi, Jakarta, 2000

Martono, Lydia H., Satya Joewana, Belajar Hidup Bertanggung Jawab, Menangkal Narkoba dan Kekerasan, Balai Pustaka, Jakarta, 2008

Badan Narkotika Nasional Republik Indonesia, Advokasi Pencegahan Penyalahgunaan Narkoba, BNN-RI, Jakarta, 2009

Gunarsa, Singgih D., Psikologi Praktis : Anak, Remaja dan Keluarga, Gunung Mulia, Jakarta, 2004

Surya, Hendra, Jadilah Pribadi Yang Unggul, Gramedia, Jakarta, 2010

Departemen Agama RI, Al Qur'an dan Terjemahnya, CV. Pustaka Agung Harapan, Surabaya, 2006

Al-Tirmidzi, Jami’ al-Shahih, III, Dar al-Fikr, t.t.

Hakim, M. Arief , Bahaya Narkoba dan Alkohol : Cara Islam Mengatasi, Mencegah dan Melawan, Nuansa, Bandung, 2004

Umar, Nasaruddin , Peran Departemen Agama dalam Pelaksanaan Terapi dan Rehabilitasi Korban Penyalahgunaan Narkoba, disajikan dalam Lokakarya Peran Institut Agama dalam Penanganan Korban Penyalahgunaan Narkoba, Badan Narkotika Nasional (BNN) RI Jakarta, 15 Agustus 2007.

Al Munawir, Ahmad Warson, Kamus Arab-Indonesia, Agustus, Yogyakarta, 1984

Al Sayis, Muhammad Ali, Tafsir Ayat al-Ahkam, Jilid 1, Ali Sabih wa Auladuh, t.t 
Penyalahgunaan Narkoba Di Kalangan Remaja Dalam Perspektif Islam

Al-Tirmidzi, Jami’ al-Shahih, III, Dar al-Fikr, t.t.

Badan Narkotika Nasional Republik Indonesia, Advokasi Pencegahan Penyalahgunaan Narkoba, BNN-RI, Jakarta, 2009

Departemen Agama RI, Al Qur'an dan Terjemahnya, CV. Pustaka Agung Harapan, Surabaya, 2006

Gunarsa, Singgih D., Psikologi Praktis : Anak, Remaja dan Keluarga, Gunung Mulia, Jakarta, 2004

Hakim, M. Arief , Bahaya Narkoba dan Alkohol : Cara Islam Mengatasi, Mencegah dan Melawan, Nuansa, Bandung, 2004

Kartono, Kartini, Patologi Sosial 2 Kenakalan Remaja, Rajawali Pers, Jakarta, 2001

Martono, Lydia H., Satya Joewana, Belajar Hidup Bertanggung Jawab, Menangkal Narkoba dan Kekerasan , Balai Pustaka, Jakarta, 2008

Partodihardjo, Subagyo, Kenali Narkoba dan Musuhi Penyalahgunaannya, Esensi, Jakarta, 2000

Sadewa, Yanuar, Bimbingan dan Penyuluhan Islam terhadap Bahaya Narkoba, Makalah Badan Narkotika Nasioal 21 Agustus 2007

Sofyan, Ahmad, Narkoba Mengincar Anak Anda, Prestasi Pustaka, Jakarta, 2007

Surya, Hendra, Jadilah Pribadi Yang Unggul, Gramedia, Jakarta, 2010

Umar, Nasaruddin , Peran Departemen Agama dalam Pelaksanaan Terapi dan Rehabilitasi Korban Penyalahgunaan Narkoba, disajikan dalam Lokakarya Peran Institut Agama dalam Penanganan Korban Penyalahgunaan Narkoba, Badan Narkotika Nasional (BNN) RI Jakarta, 15 Agustus 2007.

Undang-Undang RI No. 35 tahun 2009 tentang Narkotika 
Undang-Undang RI No. 5 tahun 1997 tentang Psikotropika

Widjaja, A.W, Masalah Kenakalan Remaja dan Penyalahgunaan Narkotika, Armico, Bandung, 2009 